\title{
Modes of Biomineralization of Magnetite by Microbes
}

\author{
Dennis A. Bazylinski \\ School of Life Sciences, University of Nevada, Las Vegas, 4505 South Maryland Parkway, Las Vegas, \\ NV 89154-4004, USA \\ Richard B. Frankel \\ Department of Physics, California Polytechnic State University, San Luis Obispo, CA 93407 \\ USA
}

\author{
Kurt O. Konhauser \\ Department of Earth and Atmospheric Sciences University of Alberta, Edmonton, \\ Alberta T6G 2E3 Canada
}

\begin{abstract}
Biomineralization processes have traditionally been grouped into two distinct modes; biologically induced mineralization (BIM) and biologically controlled mineralization (BCM). In BIM, microbes cause mineral formation by sorbing solutes onto their cell surfaces or extruded organic polymers and/or releasing reactive metabolites which alter the saturation state of the solution proximal to the cell or polymer surface. Such mineral products appear to have no specific recognized functions. On the other hand, in BCM microbes exert a great degree of chemical and genetic control over the nucleation and growth of mineral particles, presumably because the biominerals produced serve some physiological function. Interestingly, there are examples where the same biomineral is produced by both modes in the same sedimentary environment. For example, the magnetic mineral magnetite $\left(\mathrm{Fe}_{3} \mathrm{O}_{4}\right)$ is generated extracellularly in the bulk pore waters of sediments by various $\mathrm{Fe}$ (III)-reducing bacteria under anaerobic conditions, while some other anaerobic and microaerophilic bacteria and possibly protists form magnetite intracellularly within preformed vesicles. Differences in precipitation mechanisms might be caused by enzymatic activity at specific sites on the surface of the cell. Whereas one type of microbe might facilitate the transport of dissolved Fe(III) into the cell, another type will express its reductive enzymes and cause the reduction of $\mathrm{Fe}$ (III) external to the cell. Still other microbes might induce magnetite formation indirectly through the oxidation of $\mathrm{Fe}$ (II), followed by the reaction of dissolved $\mathrm{Fe}$ (II) with
\end{abstract}

We thank K. J. Edwards, B. M. Moskowitz, D. Schüler, and S. Simmons for valuable discussions; S. Glasauer for Figure 4; and two anonymous reviewers for significantly helpful comments. DAB is grateful for support from US National Science Foundation grant EAR-0311950 and National Aeronautics and Space Administration (NASA) Johnson Space Center grant NAG 9-1115. KK was supported by a Natural Sciences and Engineering Research Council award (249565-2002).

Address correspondence to Dennis A. Bazylinski, School of Life Sciences, University of Nevada, Las Vegas, 4505 South Maryland Parkway, Las Vegas, NV 89154-4004 USA E-mail: dennis. bazylinski@unlv.edu hydrolyzed Fe(III). The biomineralization of magnetite has significant effect on environmental iron cycling, the magnetization of sediments and thus the geologic record, and on the use of biomarkers as microbial fossils.

Keywords biomineralization, iron oxides, magnetite, magnetotactic bacteria, Fe(III)-reducing bacteria

\section{INTRODUCTION}

Biomineralization, the processes by which organisms form minerals, is widespread, with more than 60 biologically formed minerals identified (Bäuerlein 2000; Weiner and Dove 2003). The synthesis of minerals by bacteria has been classified according to the degree of control over the mineralization process, namely those that are formed passively or actively (Lowenstam 1981; Lowenstam and Weiner 1989).

\section{Biologically Induced Mineralization}

Minerals precipitated passively by bacteria through BIM processes generally form as a by-product of cell surface charge and/or metabolic activity. In the former case, because of their high surface to volume ratios, and the presence of functional groups on their cell walls and extracellular layers that tend to deprotonate at circumneutral $\mathrm{pH}$, bacteria can be viewed of as negatively-charged particles that interact electrostatically with dissolved cations. Once bound, those cations may contribute to a localized state of supersaturation, a condition that must be initiated and maintained for mineralization to occur (Fowle and Fein 2001). Sorption also helps to stabilize the surfaces of nascent mineral particles, decreasing the free energy barrier for critical, crystal-nucleus formation. By this means, the rate of mineralization of amorphous (poorly ordered) to weakly crystalline mineral particles may be several orders of magnitude faster than that of inorganic mineralization processes in the bulk aqueous milieu. 
The metabolic activity of some cells also induces mineralization through the release of metabolites into the surrounding solution (Frankel and Bazylinski 2003). These, in turn, react with specific ions or compounds, either in solution or already sorbed to the cell surface, resulting in the formation of mineral particles that are external to, or on, the surface of the cell (Konhauser 1998). BIM appears to be particularly significant for bacteria in anaerobic habitats or at oxic-anoxic interfaces (Frankel and Bazylinski 2003). Under anaerobic conditions, many bacteria respire with various metals (e.g., $\mathrm{Fe}(\mathrm{III}))$ and sulfate $\left(\mathrm{SO}_{4}{ }^{2-}\right)$ as terminal electron acceptors. The metabolic products of these reductions, $\mathrm{Fe}$ (II) and $\mathrm{H}_{2} \mathrm{~S}$, are reactive and participate in subsequent mineral formation. At oxic-anoxic interfaces, the oxidation of reduced metals and sulfur compounds by both biological and chemical (abiological) means, may also contribute to BIM.

The composition and properties of minerals formed through BIM depend strongly on environmental conditions (e.g., $\mathrm{pH}$, $\mathrm{pO}_{2}, \mathrm{pCO}_{2}$, Eh, temperature) (e.g., Bell et al. 1987) and are generally indistinguishable from minerals formed inorganically under the same chemical conditions; that is, the precipitated minerals that form are generally characterized by poor crystallinity, broad particle-size distributions, and lack of specific crystal morphologies (Frankel and Bazylinski 2003). In addition, the lack of control over mineral formation often results in poor mineral specificity (mixed mineral compositions) and/or the inclusion of impurities in the mineral lattice. In certain situations, metabolic products diffuse away and minerals may precipitate far from the cells that produced the reactants.

\section{Biologically Controlled Mineralization}

What makes biologically controlled biomineralization different from the processes discussed above is that the microbe exerts considerable active control over all aspects of the nucleation and mineral growth stages (Mann 1988). Initially, a specific site within the cytoplasm or on the cell wall is sealed off from the external environment, creating geochemical conditions independent from the bulk solution. Two common methods of space delineation can occur. The first involves the development of intercellular spaces between cells. The second is the formation of intracellular deposition vesicles.

Once the organic matrix is formed, the next step entails the cells sequestering specific ions of choice and transferring them to the isolated compartments where their concentrations are increased until a state of supersaturation is achieved. Levels of supersaturation are regulated by managing the rate at which mineral constituents are provided to the compartment via specific transport enzymes. Nucleation is controlled by exposing ligands with distinct stereochemical and electrochemical properties tailored to interact with specific hydrated ions. Moreover, the organic functional groups act a surrogate oxyanions that simulate the first layer of the incipient nuclei (Mann et al. 1993). The crystals then grow in a highly ordered man- ner, having their orientation, morphology and size governed by the overall ultrastructure of the membrane-bound compartment. Consequently, minerals produced by BCM are characterized by well-ordered crystals with a relatively narrow size distribution and specific, consistent morphologies (Bazylinski and Frankel 2003).

Given the specificity of the mineral product, it is likely that the precipitation process is under genetic control. Although, in the case of the magnetotactic bacteria, the actual genes responsible for the biomineralization process are not presently known, several genes are clearly involved in the construction of the magnetosome chain (Komeili et al. 2006; Scheffel et al. 2006), while others appear to encode for proteins that bind iron and that might affect the morphology of magnetite crystals formed in their presence (Arakaki et al. 2003).

For eukaryotes, such as diatoms and coccolithophores, the biomineral functions as an external skeleton that affords protection to the cell. For bacteria, the BCM process is best described in terms of the magnetotactic bacteria that form intracellular grains of pure magnetite.

\section{MAGNETITE FORMATION}

A great deal of research has focused on the potential for bacteria to contribute to the stable remnant magnetism in modern soils and sediments, and whether a biogenic magnetite component exists in the ancient geomagnetic record (e.g., Kirschvink 1982). This interest has arisen due to the recognition that a number of bacteria biomineralize magnetite crystals that are singlemagnetic domains (SD), i.e., grains with a high natural magnetic remanence. Magnetite is known to be biomineralized through both BIM and BCM.

\section{BIM Magnetite via Fe(III) Reduction}

Dissimilatory $\mathrm{Fe}(\mathrm{III})$-reducers, such as Geobacter metallireducens and Shewanella putrefaciens, are the most extensively studied bacterial species that produce crystals of magnetite as a by-product of their metabolism when grown in culture. These members of the Proteobacteria oxidize fermentation products and anaerobically reduce $\mathrm{Fe}(\mathrm{III})$ in poorly crystalline ferric oxyhydroxides as a terminal electron acceptor. In addition, a vast number of other $\mathrm{Fe}(\mathrm{III})$-reducing bacteria, including thermophilic species, form magnetite (e.g., Slobodkin et al. 1997, 1999; Zhang et al. 1997, 1998; Roh et al. 2002) in culture. In all cases, the crystals formed are clearly epicellular and are not aligned in chains (e.g., Lovley et al. 1987; Moskowitz et al. 1989; Sparks et al. 1990) (Figure 1). Some other characteristic features of these magnetite grains are poor crystallinity, nonuniform shapes, and grain sizes ranging from 10-50 nm (Figure 1). Most grains are usually found at the lower end of this size range, which means that they are superparamagnetic (they do not display a remanent magnetization at ambient temperature), as a diameter $>30 \mathrm{~nm}$ is required for permanent, single-magnetic domain behavior. However, temperature may be an important 


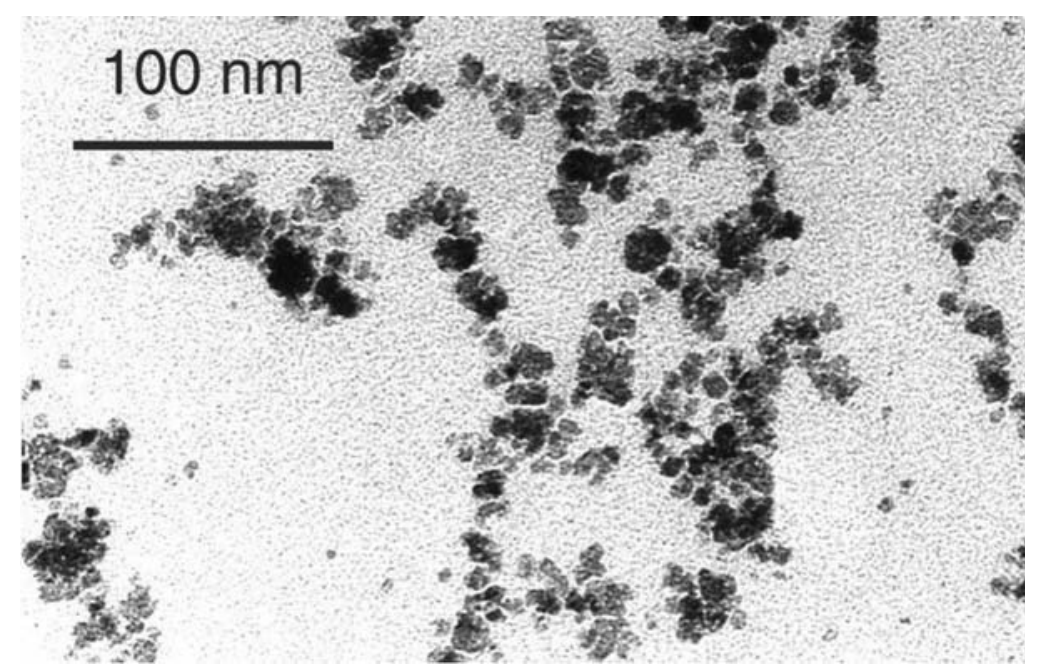

FIG. 1. Transmission electron micrograph (TEM) of nanoscale grains of magnetite formed extracellularly through biologically induced mineralization during the reduction of ferric oxyhydroxide by the dissimilatory Fe(III)-reducing bacterium Geobacter metallireducens.

factor that affects the size of magnetite grains produced through BIM in that Zhang et al. (1998) found that the major portion of the particles produced by a thermophilic Fe(III)-reducer were SD grains.

Magnetic analyses indicate that about $96 \%$ of the magnetite particles produced in culture by Geobacter metallireducens are superparamagnetic (Moskowitz et al. 1989). Not surprisingly, cells of Geobacter or Shewanella in wet mounts do not orient in response to an applied magnetic field. Despite this low percentage of single-domain magnetite, Geobacter and other Fe(III)reducing bacteria might still be a major contributor to the SD fraction because on a per-cell basis, under the proper conditions, they could theoretically generate some 5,000 times more magnetite than a magnetotactic bacterium. The amount of magnetite produced is primarily limited by the amount of $\mathrm{Fe}(\mathrm{III})$ present in the culture that is available for reduction by cells (Frankel 1987). Culture conditions may also play a role in the size and the degree of crystallinity of magnetite grains produced by $\mathrm{Fe}(\mathrm{III})$-reducing bacteria. For example, under $\mathrm{CO}_{2}$-rich culture conditions, cells of $G$. metallireducens are known to produce mainly superparamagnetic grains of magnetite as described above (Moskowitz et al. 1989). In a recent study, cells of this species were found to produce a unique form of tabular, SD-grained of magnetite in cultures that were low in $\mathrm{CO}_{2}$ (Vali et al. 2004). These grains have a distinct crystal habit and magnetic properties and, like some other forms of magnetite, could be used as a biosignature for ancient biological activities in terrestrial and extraterrestrial environments and also may be a major carrier of the magnetization in natural sediments.

The actual role that $\mathrm{Fe}(\mathrm{III})$-reducing bacteria play in magnetite formation in natural environments remains unresolved. On the face of it, the inorganic reaction of $\mathrm{Fe}$ (II) (produced during Fe(III) reduction) with the remaining ferric hydroxide should be sufficient to precipitate magnetite. Early experimental studies without bacteria showed that magnetite did not form even under what was thought to be appropriate chemical conditions (Lovley 1990). Furthermore, magnetite did not form if cultures were incubated at temperatures too high for growth, if the inoculated medium was sterilized prior to incubation or if nongrowing cells were added to the experimental solution.

However, Hansel et al. (2003) showed that, in fact, magnetite can be abiotically formed (without cells) through the reaction of $\mathrm{Fe}$ (II) with ferrihydrite at circumneutral $\mathrm{pH}$. The major difference between this work and that of Lovley (1990) is that $\mathrm{mM}$ levels of inorganic phosphate were present in the culture medium of Lovley (1990). Inorganic phosphate is known to adsorb strongly to ferrihydrite probably inhibiting the conversion of ferrihydrite to magnetite. A Pipes buffer system was used in the abiotic experiments described by Hansel (2003) and inorganic phosphate was absent. Because most natural, aquatic systems do not contain high levels of inorganic phosphate, the experiments and results of Hansel et al. (2003) might be more important with regard to magnetite precipitation via $\mathrm{Fe}(\mathrm{III})$ reduction in natural environments. However, it is also arguable whether the presence of organic buffers such as Pipes represent a situation that can be extrapolated to many environmental conditions where fine-grained magnetite has been found.

Given the discussion in the previous paragraph, the metabolism of the $\mathrm{Fe}(\mathrm{III})$-reducing bacteria must contribute more than just $\mathrm{Fe}$ (II) to magnetite biomineralization in solutions containing high levels of inorganic phosphate typical of bacterial growth media. One possibility is that magnetite formation is favored by high $\mathrm{pH}$; a condition met during Fe(III)reduction [reaction 1]. The $\mathrm{Fe}(\mathrm{II})$ that forms then adsorbs onto other ferric hydroxide grains, where it is transformed into magnetite [reaction 2]. Perhaps then the appropriate combination of a high $\mathrm{Fe}(\mathrm{II})$ concentration and high $\mathrm{pH}$ at the contact of the 
Fe(III) solid provides an ideal interface for secondary magnetite formation (Lovley 1990).

$$
\begin{aligned}
\mathrm{CH}_{3} \mathrm{COO}^{-}+8 \mathrm{Fe}(\mathrm{OH})_{3} \rightarrow & 8 \mathrm{Fe}^{2+}+2 \mathrm{HCO}_{3}{ }^{-}+15 \mathrm{OH}^{-} \\
& +5 \mathrm{H}_{2} \mathrm{O} \\
2 \mathrm{OH}^{-}+\mathrm{Fe}^{2+}+2 \mathrm{Fe}(\mathrm{OH})_{3} \rightarrow & \mathrm{Fe}_{3} \mathrm{O}_{4}+4 \mathrm{H}_{2} \mathrm{O}
\end{aligned}
$$

More recently, magnetite has also been shown to form by microbial reduction of lepidocrocite $(\gamma-\mathrm{FeOOH})$, a polymorph of goethite (Cooper et al. 2000). In this case, the actual step in magnetite formation proceeds inorganically via a ferrous hydroxide intermediate [reaction 3].

$$
\begin{aligned}
& {[\gamma-\mathrm{FeOOH}]_{2}+\mathrm{Fe}^{2+}+\mathrm{H}_{2} \mathrm{O} \rightarrow[\gamma-\mathrm{FeOOH}]_{2} \cdot \mathrm{FeOH}^{+}} \\
& +\mathrm{H}^{+} \rightarrow \mathrm{Fe}_{3} \mathrm{O}_{4}+\mathrm{H}_{2} \mathrm{O}+2 \mathrm{H}^{+}
\end{aligned}
$$

Recent studies have now additionally shown that microbially induced magnetite formation does not strictly require the activity of Fe(III)-reducing bacteria. In experiments where Fe(II) was added to cultures of Dechlorosoma suillum, with nitrate as the terminal electron acceptor, the bacteria induced the precipitation of a greenish-gray, mixed $\mathrm{Fe}$ (II)-Fe(III) hydroxide, known as green rust. This mineral is generally unstable in the environment, and further oxidation led to the formation of magnetite within just 2 weeks (Chaudhuri et al. 2001). Meanwhile, other experimental studies have documented magnetite formation in association with suspended cultures of phototrophic $\mathrm{Fe}(\mathrm{II})$-oxidizing bacteria, through the reaction of $\mathrm{Fe}(\mathrm{II})$ with biogenic ferric hydroxide precipitates (Jiao et al. 2005).

In modern marine and freshwater sediments, much of the magnetite forms in the suboxic layers where Fe(III) reduction takes place (e.g., Karlin et al. 1987). It has been found associated with gas seeps and solid bitumen as well, where its formation appears to be linked to the reduction of ferric oxyhydroxides and microbial hydrocarbon biodegradation (e.g., McCabe et al. 1987). This process is supported by experimental findings of magnetite accumulation during toluene oxidation coupled to $\mathrm{Fe}(\mathrm{III})$-reduction by G. metallireducens (Lovley and Lonergan 1990).

Similar processes likely played a role in the geological past. For instance, the presence of diagentic magnetite in Precambrian banded iron formations, including (1) magnetite overgrowths on hematite, (2) laminated magnetite beds that clearly truncate sedimentary layering, and (3) cleavage fills (Ewers and Morris 1981; Krapež et al. 2003) point to the secondary nature of the magnetite. As described above, some of this magnetite could be formed through an inorganic reaction of $\mathrm{Fe}(\mathrm{II})$ with $\mathrm{Fe}(\mathrm{OH})_{3}$, or alternatively, through the partial oxidation of primary siderite [reaction 4]. However, the capacity of extant hyperthermophilic Bacteria and Archaea (that branch deeply in the universal phylogenetic tree) to reduce Fe(III) (Vargas et al. 1998), and the recent observations of highly negative $\delta^{56} \mathrm{Fe}$ values in magnetite-rich
BIF samples as old as $2.9 \mathrm{Ga}$ (Johnson et al. 2003; Yamaguchi et al. 2005), with comparable negative fractionations as observed in experimental culture with dissimilatory Fe(III)-reducing bacteria (Johnson et al. 2005), point towards the antiquity of such an anaerobic respiratory pathway in shaping the mineralogical component of the Fe-rich marine sediments. Significantly, coupling the reduction of $\mathrm{Fe}(\mathrm{III})$ minerals to the oxidation of organic matter not only explains the low content of organic carbon in the BIFs (Walker 1984), but it also explains the abundance of light carbon isotopic signatures associated with the interlayered carbonate minerals (Walker 1984; Baur et al. 1985).

$$
\mathrm{FeCO}_{3}+2 \mathrm{Fe}(\mathrm{OH})_{3} \rightarrow \mathrm{Fe}_{3} \mathrm{O}_{4}+3 \mathrm{H}_{2} \mathrm{O}+\mathrm{CO}_{2}
$$

\section{BCM Magnetite by Magnetotactic Bacteria}

Magnetotactic bacteria are a diverse group of mainly aquatic, Gram-negative bacteria that align and swim along geomagnetic field lines, a phenomenon referred to as magnetotaxis (Blakemore 1975, 1982). These bacteria biomineralize intracellular, membrane-bounded crystals of magnetite and/or the iron sulfide greigite $\left(\mathrm{Fe}_{3} \mathrm{~S}_{4}\right)$ called magnetosomes. These structures appear to be anchored to the cell membrane, and are usually aligned in a chain or chains (Figure 2).

Magnetotactic bacteria have been recovered from freshwater swamps and ponds, river sediment, anoxic freshwater sediment, soils, marine salt marshes and estuaries, evaporates, marine waters and sediment (Bazylinski and Moskowitz 1997). They are most abundant at oxic-anoxic interfaces, which in most sediments, occurs at or just below the sediment-water interface. In euxinic basins it occurs at some depth in the water column. All are chemoheterotrophic and some are facultatively chemolithoautotrophic (Bazylinski et al. 2004; Williams et al. 2006), with oxygen their usual terminal electron acceptor, although cells such as Magnetospirillum magnetotacticum strain MS-1 produce more magnetite when grown with nitrate $\left(\mathrm{NO}_{3}^{-}\right)$, but they still require at least $1 \% \mathrm{O}_{2}$ for magnetite synthesis (Blakemore et al. 1985). Other magnetotactic bacteria can use $\mathrm{NO}_{3}^{-}$or nitrous oxide $\left(\mathrm{N}_{2} \mathrm{O}\right)$ anaerobically and produce magnetite without molecular $\mathrm{O}_{2}$ and there is some evidence that some may be able to use Fe(III) (Short and Blakemore 1986).

Unlike the magnetite produced passively, the crystals in magnetotactic bacteria are of high chemically purity (Bazylinski and Frankel 2003). The crystal habits of the magnetite crystals are also consistent within a given species or strain (Figure 2), although subtle variations of shape and size has been observed within cells of the same species grown under different conditions (Meldrum et al. 1993). While some magnetotactic bacteria produce equidimensional crystal shapes where all symmetryrelated crystal faces develop equally, several nonequidimensional shapes have been described in other species or strains; although both equidimensional and nonequidimensional 

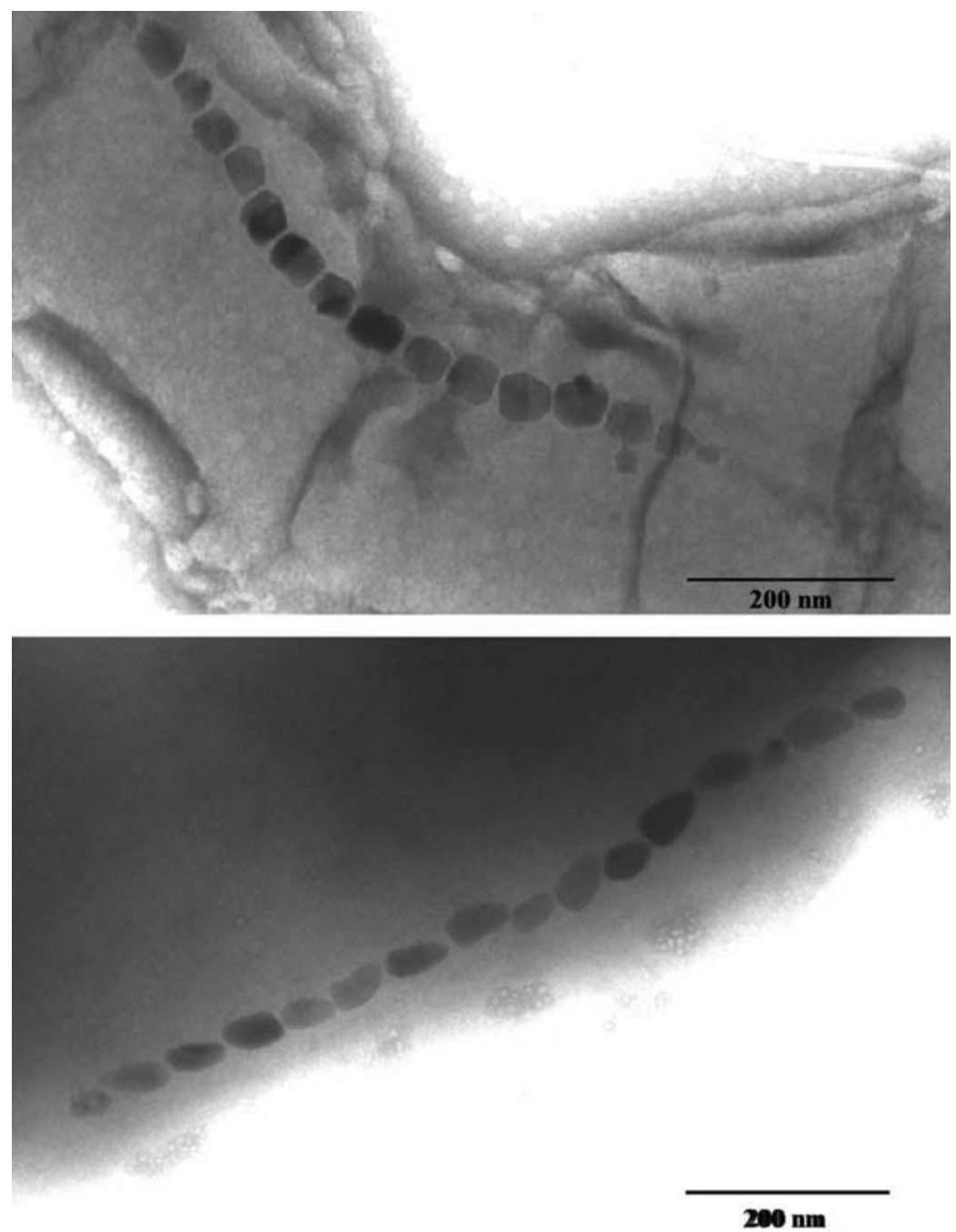

FIG. 2. Magnetite grains produced through biologically controlled mineralization in cells of different magnetotactic bacteria. Upper, TEM of a negatively-stained cell of a new magnetotactic spirillum that biomineralizes cubo-octahedral grains of magnetite. Lower, TEM of a negatively-stained cell of Desulfovibrio magneticus strain RS-1, a species which biomineralizes tooth-shaped grains of magnetite.

magnetite crystals have the same face-centered cubic crystal structure.

Magnetosome magnetite crystals typically have crystal size distributions which peak in the 35 to $120 \mathrm{~nm}$ size range (Bazylinski and Frankel 2000). Crystals of magnetite (and greigite) in this size range are permanent, single-magnetic domains at ambient temperature (Butler and Banerjee 1975). Smaller crystals are superparamagnetic whereas larger crystals are metastable SD or support formation of domain walls. Therefore, SD crystals have the largest possible remnant magnetization. Magnetotactic interactions between the SD magnetosomes organized in a chain cause the individual grain moments to orient parallel to each other along the chain direction. Thus the chain has a permanent magnetic dipole approximately equal in magnitude to the sum of the individual magnetosome magnetic moments.
By producing SD particles, the bacterium has maximized the remanent magnetic moment of the individual grains, and by arranging the grains in chains, it has also maximized the magnetic moment of the cell for the number and size of magnetosomes produced (Bazylinski and Frankel 2004). The permanent magnetic dipole moment of the cell is generally robust enough so that its interaction with the geomagnetic field overcomes the thermal forces tending to randomize the orientation of the magnetic dipole in its aqueous surroundings (Frankel 1984). Since the dipole is fixed in the cell, orientation of the dipole results in orientation of the cell. Magnetotaxis results as the oriented cell swims along magnetic field lines (Frankel et al. 1997).

How magnetotactic bacteria biomineralize magnetosomes is not fully resolved, but it clearly involves considerable energy expenditure by the cells that form it since they can take up enough iron to make up $>3 \%$ of their mass as iron (dry cell 


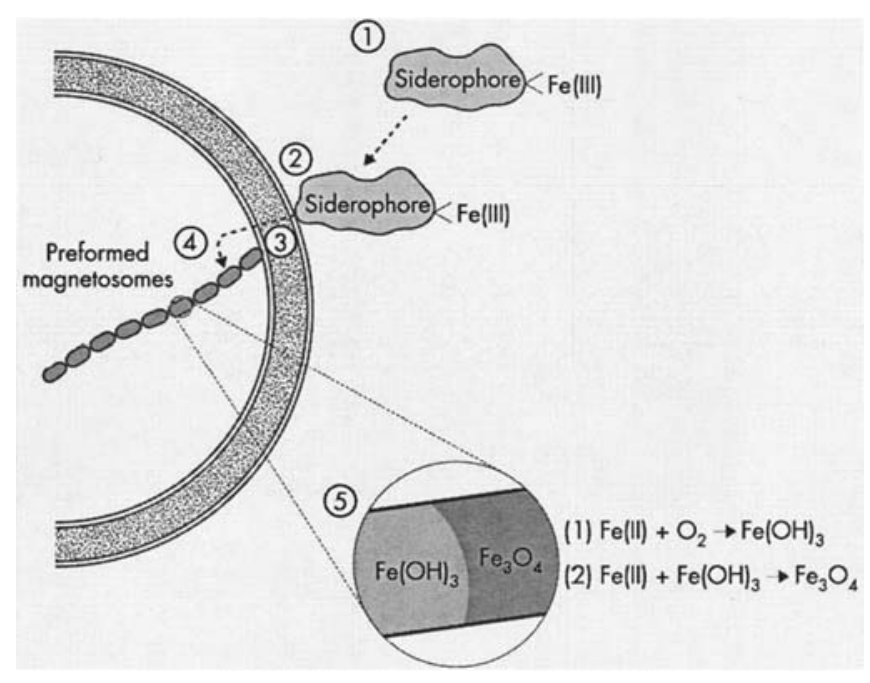

FIG. 3. Possible mechanisms by which magnetotactic bacteria form intracellular magnetite. There are a number of steps involved, including (1) sequestration of $\mathrm{Fe}$ (III) from the aqueous environment via siderophores; (2) siderophore attachment to a receptor site on the outer membrane; (3) transport of the siderophore through the outer membrane to the plasma membrane, where Fe(III) is reduced to $\mathrm{Fe}$ (II); (4) transport of $\mathrm{Fe}$ (II) to pre-formed magnetosome; and (5) initial precipitation of ferric hydroxide within the magnetosome, followed by transformation to magnetite. The size of siderophore is not to scale. From Konhauser (2007). Reproduced with permission from Blackwell Publishing.

weight basis) (Blakemore 1982; D. Schüler personal communication). Magnetite synthesis involves a series of geochemical steps that begins with the uptake of iron from the surrounding environment (Figure 3). Bacteria commonly rely on iron chelators such as siderophores to facilitate the solubilization and transport of ferric iron to the cell. Once a specific siderophore has sequestered iron, it then needs to be absorbed by a cell that requires it.

This is accomplished by cell synthesis of specific receptor proteins designed first to recognize the Fe(III)-siderophore complex and then, with the aid of other transport proteins, guide the coordinated iron to the plasma membrane or directly into the cytoplasm (Neilands 1989). The Fe(III) is then reduced to Fe(II) by either the siderophore itself or by a Fe(III)-reductase, and shuttled in some form into the cell and then through the cytoplasm into what many consider to be a magnetosome membrane vesicle. However, results from Komeili et al. (2006) suggest that the magnetosome membrane structures are not vesicles at all and are actually permanent invaginations of the cell membrane.

Regardless of whether these structures are truly vesicles or not, the magnetosome membrane in Magnetospirillum magneticum strain AMB-1 clearly results from an invagination of the cell membrane and it appears to be preformed prior to the mineralization of magnetite (Komeili et al. 2004, 2006). Empty or partially empty magnetosome "vesicles" have been observed in iron-starved cells, and recent molecular work has shown that the specific magnetosome-associated protein MamA is required for activation of the formation of the magnetosome membrane structures prior to biomineralization (Komeili et al. 2004), although the precise role of MamA and most other magnetosomeassociated proteins in magnetosome synthesis is unknown. In the magnetosome "vesicle," Fe(II) is then presumably re-oxidized into ferric hydroxide (perhaps with $\mathrm{O}_{2}$ as the ultimate electron acceptor), a mineral previously observed intracellularly in magnetotactic bacteria (Frankel et al. 1983). The actual crystallization of magnetite then involves the reaction of the ferric hydroxide with excess dissolved Fe(II) [reaction 5].

$$
\mathrm{Fe}^{2+}+2 \mathrm{OH}^{-}+2 \mathrm{Fe}(\mathrm{OH})_{3} \rightarrow \mathrm{Fe}_{3} \mathrm{O}_{4}+4 \mathrm{H}_{2} \mathrm{O}
$$

It should be noted however that Schüler and Baeuerlein (1998) showed that, in Magnetospirillum gryphiswaldense, $\mathrm{Fe}(\mathrm{III})$ is taken up and rapidly converted to $\mathrm{Fe}_{3} \mathrm{O}_{4}$ without delay, indicating that no significant accumulation of an $\mathrm{Fe}_{3} \mathrm{O}_{4}$ precursor occurs inside the cell, at least under the microaerobic conditions of the experiment, which were apparently optimal for $\mathrm{Fe}_{3} \mathrm{O}_{4}$ production by $M$. gryphiswaldense.

The subsequent adsorption of Fe(II) ions on the solid ferric iron surface has been suggested as the possible trigger for magnetite formation, with the solid-state rearrangement shown as a growing crystal front of magnetite extending into the amorphous iron oxide (Mann et al. 1984). This mineralization scenario is in part borne out by the observations that some bacteria capable of dissimilatory Fe(III)-reduction (e.g., Shewanella putrefaciens) under anaerobic conditions produce a large number of small (30-50 nm in diameter), intracellular grains of ferric hydroxide that are partially composed of small amounts of magnetite and/or maghemite $\left(\gamma-\mathrm{Fe}_{2} \mathrm{O}_{3}\right)$ that appear to be surrounded by a membrane or membrane-like structure (Figure 4) (Glasauer et al. 2002). This latter case appears to be an example of biomineralization that is intermediate between BIM and $\mathrm{BCM}$ as the mineral grains have qualities of minerals produced by both processes.

To complicate matters, the precipitation process requires values of Eh and $\mathrm{pH}$ for which magnetite is the stable iron oxide mineral. This implies that the magnetosome membrane controls the chemical conditions in the "vesicle," as well as controlling magnetite morphology and size (Gorby et al. 1988).

\section{Magnetite in Eukaryotic Microbes}

A number of diverse protists from coastal areas have been found to contain what clearly seem to be BCM-type magnetite grains (Torres de Araujo et al. 1986; Bazylinski et al. 2000). Although the origin of the magnetite is presently not known, two possibilities can be considered. The first is that these organisms may be consuming magnetotactic bacteria and somehow incorporating the cells and/or magnetosomes within themselves. One type, a biflagellate common to coastal sites in New England, sometimes contains large, dark-orange, spherical inclusions within the cells that are extruded from the cell without apparent detriment to the cell (Bazylinski et al. 2000). The 


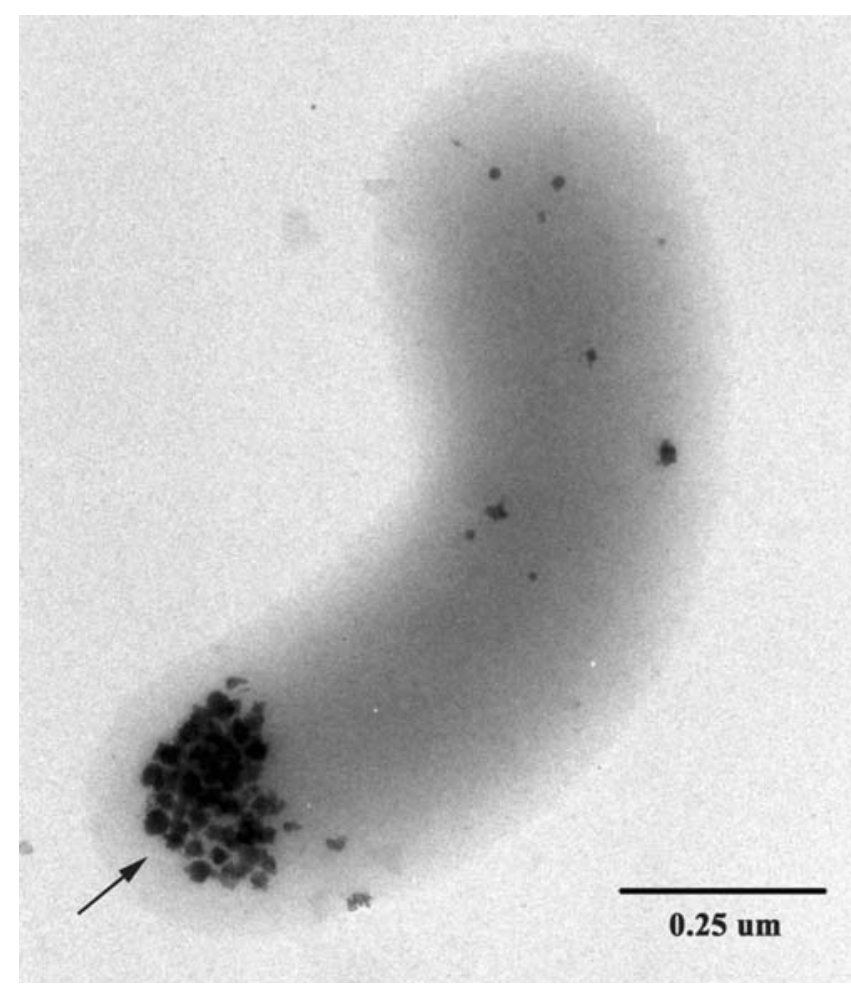

FIG. 4. TEM of a cell of Shewanella putrefaciens grown anaerobically in an $\mathrm{H}_{2}$ /Ar atmosphere with poorly crystalline ferrihydrite (ferric oxyhydroxide) as the electron acceptor. Cells grown under these conditions biomineralize intracellular grains of ferric hydroxide (at arrow) that are partially composed of magnetite and/or maghemite $\left(\gamma-\mathrm{Fe}_{2} \mathrm{O}_{3}\right)$ (Glasauer et al. 2002). Image courtesy of Susan Glasauer.

extruded inclusions reorient in response to reversals of the magnetic field while the protistan cell no longer shows a magnetic response. Although none of the magnetic protistan cells were ever observed engulfing magnetotactic bacteria, which are abundant at the sites and clearly present in collected water samples, it is possible that these inclusions represent indigestable or partially digestible material including magnetosomes from ingested bacteria in vacuoles. Structures resembling endosymbiotic magnetotactic bacteria were not observed.

The second possibility is that some protists biomineralize endogenous magnetite grains. Many of the magnetically responsive protists contain magnetite grains of consistent size (SD grains) and uniform morphology, possess a permanent magnetic dipole moment and clearly show a directional preference as in the magnetotactic bacteria; generally north-seeking in the Northern Hemisphere. In the case of a magnetically-responsive Euglenoid alga discovered in a lagoon in Brazil tentatively identified as Anisonema platysomum (Torres de Araujo et al. 1986), the organization of the tooth-shaped magnetosomes is elaborate and the magnetite grains are arranged as multiple, linear clusters of chains along the long axis of the cell (Figure 5). Together, these findings suggest a biomineralization process in some protists that is more complicated than the simple consumption of mag- netotactic bacteria. It is obviously possible that both situations can occur but in different types of protists.

Regardless of the origin of protistan magnetite, these organisms contain a significant amount of intracellular iron and may play an important role in iron cycling in the aquatic habitats where they are found. Iron is well-recognized as a limiting factor in primary production in some oceanic areas and is often present in seawater in particulate and colloidal forms. Barbeau et al. (1996) showed that digestion of colloidal iron in the food vacuoles of protozoans during grazing of particulate and colloidal matter might generate more bioavailable iron for other species (e.g., phytoplankton). In coastal areas, protists that ingest magnetotactic bacteria might be important in iron cycling by solubilizing iron in magnetosomes while those that biomineralize magnetite, like the magnetotactic bacteria, may tie up iron in the form of magnetosomes thereby making a significant amount of iron unavailable for organisms. If this is the case, then these organisms, also like the magnetotactic bacteria, might directly contribute to the magnetization of sediments.

\section{Other Examples of Microbial Biomineralization of Magnetite or Magnetic Minerals That Might Include Magnetite}

Recently, magnetite grain formation was reported to occur in aerobic, aqueous mixtures of potassium ferricyanide/ferrocyanide containing cells of an aerobic bacterium, an Actinobacter species, which was a contaminant in the solutions (Bharde et al. 2006). After $24 \mathrm{~h}$ of incubation with cells of this organism, magnetite grains formed that were crystalline, roughly spherical, and ranged in size from about $1-40 \mathrm{~nm}$. After $48 \mathrm{~h}$, uniform cubic grains were observed that had 50-150 $\mathrm{nm}$ edge lengths and were thought to result from assembly of the spherical particles. Two proteins produced by the bacterium were purified and appear to catalyze the same reaction without the presence of whole cells. Other bacterial strains were tested and magnetite did not form. Whether this finding has environmental significance is unknown.

Several purple photosynthetic bacteria produce intracellular, "magnet-sensitive," electron-dense particles when cultured in growth media containing relatively high concentrations of iron (Vainshtein et al. 1997). The inclusions are spherical and contain an electron-transparent core surrounded by an electron-dense matrix and can be separated from lysed cells. X-ray microanalysis showed that the inclusions are Fe-rich but did not contain sulfur. Magnetite has not yet been identified as a component of these structures but given their magnetic properties and the lack of sulfur in them, it is possible.

The particles are arranged in a chain similar to magnetosomes and possibly surrounded by a membranous structure (Vainshtein et al. 1997). Other non-photosynthetic members of both prokaryotic domains have been shown to produce similar particles (Vainshtein et al. 2002). Cells with the particles displayed a "magnetic response" but were not necessarily magnetotactic. 

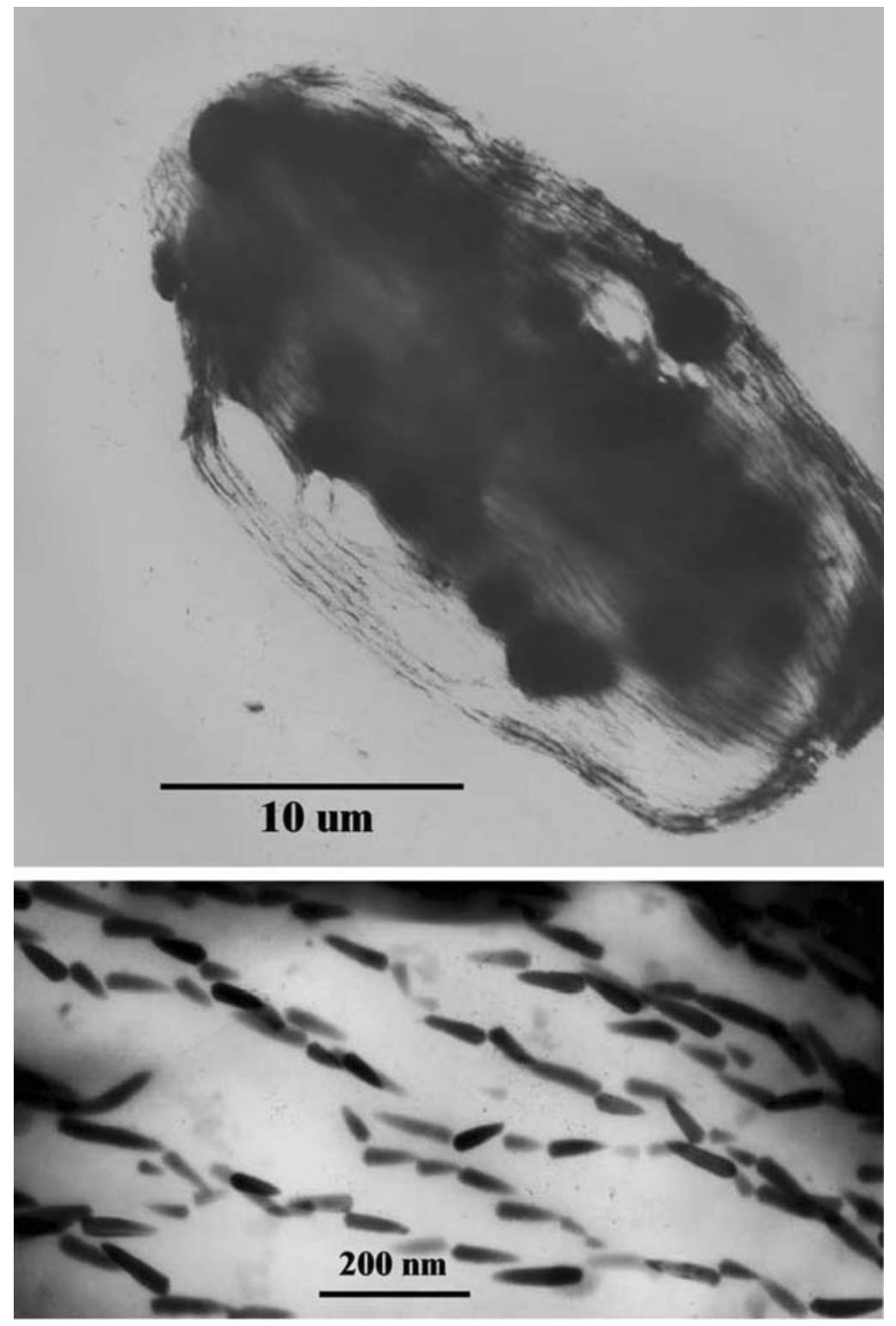

FIG. 5. Upper, TEM a negatively-stained cell of a magnetotactic alga collected in Brazil tentatively identified as Anisonema platysomum (Torres de Araujo et al. 1986). Long chains of magnetite crystals traverse the cell along its long axis. Lower, high magnification electron micrograph of chains of tooth-shaped magnetite crystals within the cell.

This case of biomineralization appears to be intermediate between BIM and BCM in that cells appear to control some features of these particles such as their arrangement in the cell.

\section{THE SIGNIFICANCE OF MAGNETITE}

There is likely no advantage to formation of magnetite by $\mathrm{Fe}$ (III)-reducing bacteria. But the specificity of the BCM process suggests that magnetite formation is advantageous for magnetotactic bacteria. At present we can only speculate on some of the advantages, the most likely being that magnetotaxis allows a bacterium to keep its heading as it swims in the face of the disorienting Brownian buffeting by the medium. This allows cells to make straight excursions, increasing the cell's chemotactic efficiency. It also allows cells to sequentially access different chemical zones in a chemically stratified environment. Most magnetotactic bacteria are microaerophilic (Bazylinski and Frankel 2004), but straight excursions, to higher concentrations of oxidant and reductant, just above and below the redoxcline, respectively, might increase the metabolic rate of the cells (Frankel et al. 2006). However, cells can prevent long excursions, in which cells inadvertently move too far upwards, and the concentration of oxygen becomes inhibitory, or too far downwards, where hydrogen sulfide concentrations are prohibitively 
high, by reversing swimming direction without physically turning around (Frankel et al. 1997). Like most free-swimming bacteria, magnetotactic bacteria propel themselves in their aqueous environment by rotating their helical flagella. Cells presumably reverse direction by reversing the direction of their flagellar motors (Frankel et al. 1997).

Yet, if knowing which way is up versus down increases a cell's efficiency at finding and maintaining an optimal position relative to the gradient, why then don't all bacteria inhabiting suboxic sediments have magnetic properties? Moreover, nonmagnetotactic mutants of some strains still form microaerobic bands of cells at the oxic-anoxic interface without the help of magnetosomes (D.A. Bazylinski unpublished). These observations suggest that there may be other reasons or benefits, perhaps physiological ones unrelated to magnetotaxis, for cells to expend a significant amount of energy taking up large amounts of iron and biomineralizing magnetosomes. Several of these benefits have been discussed in the past but none have been widely accepted. There is no evidence that magnetite is a storage product for iron, in fact, there is evidence that cells of magnetotactic bacteria cannot utilize the iron once precipitated as magnetite (Dubbels et al. 2004).

Interestingly, storing iron in the form of magnetite (without a protein matrix) would be extremely efficient in that it would conserve intracellular space as it is a compact, nonhydrated iron oxide. It is also relatively inert and nontoxic. Lastly magnetite, like other iron-containing compounds, reacts and destroys hydrogen peroxide (Blakemore 1982) and likely oxygen radicals produced during oxygen respiration. The lack of enzymes to destroy these toxic products has been used as an explanation of why certain prokaryotes are microaerophiles (Krieg and Hoffman 1986). There is no evidence, however, that magnetite in magnetosomes functions in this way in the cell.

Irrespective of why sedimentary magnetite is formed, the fact that it is associated with microbial activity has important implications for understanding the geochemical roles of microbes in ancient sediments. Indeed, understanding the origin of life and the evolutionary diversification of prokaryotes and single-celled eukaryotes has generally proved to be a difficult, if not impossible, task because of the lack of unequivocal, recognizable microbial fossils (Armstrong and Brasier 2005). Much of the material previously thought or believed by some to be fossilized microbes is subject to alternate interpretations. For example, microbiallike remains that supposedly represent cyanobacterial species from some of the oldest rocks on Earth, 3.5 billion year old cherts from western Australia (Schopf and Packer 1987; Schopf 1993), have recently been the subject of intense debate (Brasier et al. 2002; Dalton 2002).

However, if mineral grains produced though BIM or BCM are unique or unusual enough that they can be easily recognized and accepted as not being abiologically formed by geological or chemical processes alone, and persist over long periods of geologic time, they might prove be excellent fossil evidence for the past presence of certain microbes. Certain types of magnetite crystals, like those produced through BCM by magnetotactic bacteria and possibly protists, might fit these criteria. For example, it has been proposed that such magnetite may persist in deep-sea sediments, and thus contribute to the palaeomagnetic record (e.g., Kirschvink and Chang 1984) and that magnetite grains with a specific elongated crystal morphology are biomarkers for the past presence of magnetotactic bacteria on ancient Mars (Thomas-Keprta 2000, 2001; Clemett et al. 2002).

Despite the magnetite chains fragmenting upon lysis of the cell, their initial presence can be inferred by observing the morphological/chemical characteristics of magnetically separated fractions of sediment under an electron microscope, and also by using a magnetometer to measure the resistance to demagnetization that distinguishes multidomain from SD magnetite grains (e.g., Petersen et al. 1986). Fossil magnetotactic bacteria may even extend as far back as the Precambrian, with magnetofossils extracted from the 2.0 Gyr Gunflint Iron Formation possibly representing the oldest evidence of controlled biomineralization (Chang et al. 1989).

\section{CONCLUDING COMMENTS}

Microbes are involved in the biomineralization of many minerals. However, most of these minerals are produce by BIM processes, and only a few good examples of minerals biomineralized by both BIM and BCM processes have been reported. Magnetite remains as the best characterized of these examples and it is interesting and important that magnetite produced by both processes can be formed almost side by side in certain environments. Taking into consideration the significance of microbially produced magnetite in natural environments as discussed in this review, and the lack of information on the biochemical and chemical mechanisms in the BCM formation of magnetite in magnetotactic bacteria, it is likely that the biomineralization of magnetite by microbes will be studied for some time in the future.

\section{REFERENCES}

Arakaki A, Webb J, Matsunaga T. 2003. A novel protein tightly bound to bacterial magnetite particles in Magnetospirillum magneticum strain AMB-1. J Biol Chem 278:8745-8750.

Armstrong HA, Brasier MD. 2005. Microfossils, 2nd ed. Blackwell Publishing, Oxford, UK.

Barbeau K, Moffett JW, Caron DA, Croot PL, Erdner DL. 1996. Role of protozoan grazing in relieving iron limitation of phytoplankton. Nature 380:61-64.

Bäuerlein E. 2000. Biomineralization: From Biology to Biotechnology and Medical Application. Wiley-VCH, Weinheim, Germany. 294 p.

Baur ME, Hayes JM, Studley SA, Walter MR. 1985. Millimeter-scale variations of stable isotope abundances in carbonates from banded iron-formations in the Hamersley Group of Western Australia. Econ Geol 80:270-282.

Bazylinski DA, Frankel RB. 2000. Magnetic iron oxide and iron sulfide minerals within organisms. In Bäuerlein E, editor. Biomineralization: From Biology to Biotechnology and Medical Application. Wiley-VCH, Weinheim, Germany. P 25-46.

Bazylinski DA, Frankel RB. 2003. Biologically controlled mineralization in prokaryotes. Rev Mineral Geochem 54:95-114. 
Bazylinski DA, Frankel RB. 2004. Magnetosome formation in prokaryotes. Nature Rev Microbiol 2:217-230.

Bazylinski DA, Dean AJ, Williams TJ, Long LK, Middleton SL, Dubbels BL. 2004. Chemolithoautotrophy in the marine, magnetotactic bacterial strains MV-1 and MV-2. Arch Microbiol 182:373-387.

Bazylinski DA, Schlezinger DR, Howes BL, Frankel RB, Epstein SS. 2000. Occurrence and distribution of diverse populations of magnetic protists in a chemically-stratified coastal salt pond. Chem Geol 169:319-328.

Bell PE, Mills AL, Herman JS. 1987. Biogeochemical conditions favoring magnetite formation during anaerobic iron reduction. Appl Environ Microbiol 53:2610-2616.

Bharde A, Wani A, Shouche Y, Joy PA, Prasad BLV, Sastry M. 2005. Bacterial aerobic synthesis of nanocrystalline magnetite. J Am Chem Soc 127:93269327.

Blakemore RP. 1975. Magnetotactic bacteria. Science 190:377-379.

Blakemore RP. 1982. Magnetotactic bacteria. Annu Rev Microbiol 36:217238.

Blakemore RP, Short K, Bazylinski DA, Rosenblatt C, Frankel RB. 1985. Microaerobic conditions are required for magnetite formation within Aquaspirillum magnetotacticum. Geomicrobiol J 4:53-71.

Brasier MD, Green OR, Jephcoat AP, Kleppe AK, Van Kranendonk MJ, Lindsay JF, Steele A, Grassineau NV. 2002. Questioning the evidence for Earth's oldest fossils. Nature 416:76-81.

Butler RF, Banerjee SK. 1975. Theoretical single-domain grain size range in magnetite and titanomagnetite. J Geophys Res 80:4049-4058.

Chang S-BR, Stolz JF, Kirschvink JL, Awramik SM. 1989. Biogenic magnetite in stromatolites. II. Occurrence in ancient sedimentary environments. Precamb Res 43:305-315.

Chaudhuri SK, Lack JG, Coates JD. 2001. Biogenic magnetite formation through anaerobic biooxidation of Fe(II). Appl Environ Microbiol 67:2844-2847.

Clemett SJ, Thomas-Keprta KL, Shimmin J, Morphew M, McIntosh JR, Bazylinski DA, Kirschvink JL, McKay DS, Wentworth SJ, Vali H, Gibson Jr EK, Romanek CS. 2002. Crystal morphology of MV-1 magnetite. Am Mineral 87:1727-1730.

Cooper DC, Picardal F, Rivera J, Talbot C. 2000. Zinc immobilization and magnetite formation via ferric oxide reduction by Shewanella putrefaciens 200. Environ Sci Technol 34:100-106.

Dalton R. 2002. Squaring up over ancient life. Nature 417:782-784.

Dubbels BL, DiSpirito AA, Morton JD, Semrau JD, Neto JNE, Bazylinski DA. 2004. Evidence for a copper-dependent iron transport system in the marine, magnetotactic bacterium strain MV-1. Microbiology 150:29312945.

Ewers WE, Morris RC. 1981. Studies of the Dales Gorge Member of the Brockman Iron Formation, Western Australia. Econ Geol 76:19291953.

Fowle DA, Fein JB. 2001. Quantifying the effects of Bacillus subtilis cell walls on the precipitation of copper hydroxide from aqueous solution. Geomicrobiol J 18:77-91.

Frankel RB. 1984. Magnetic guidance of organisms. Annu Rev Biophys Bioeng 13:85-103.

Frankel RB. 1987. Anaerobes pumping iron. Nature 330:208.

Frankel RB, Bazylinski DA. 2003. Biologically induced mineralization by bacteria. Rev Mineral Geochem 54:217-247.

Frankel RB, Williams TJ, Bazylinski DA. 2006. Magneto-aerotaxis. In: Schüler $\mathrm{D}$, editor. Magnetoreception and Magnetosomes in Bacteria. Springer-Verlag, Berlin, Germany. P. 1-24.

Frankel RB, Bazylinski DA, Johnson M, Taylor BL. 1997. Magneto-aerotaxis in marine, coccoid bacteria. Biophys J 73:994-1000.

Frankel RB, Papaefthymiou GC, Blakemore RP, O'Brien W. 1983. Fe3O4 precipitation in magnetotactic bacteria. Biochim Biophys Acta 763:147-159.

Glasauer S, Langley S, Beveridge TJ. 2002. Intracellular iron minerals in a dissimilatory iron-reducing bacterium. Science 295:117-119.

Gorby YA, Beveridge TJ, Blakemore RP. 1988. Characterization of the bacterial magnetosome membrane. J Bacteriol 170:834-841.
Hansel CM, Benner SG, Neiss J, Dohnalkova A, Kukkadapu RK, Fendorf S. 2003. Secondary mineralization pathways induced by dissimilatory iron reduction of ferrihydrite under advective flow. Geochim Cosmochim Acta 67:2977-2992.

Jiao Y, Kappler A, Croal LR, Newman DK. 2005. Isolation and characterization of a genetically tractable photoautotrophic Fe(II)-oxidizing bacterium, Rhodopseudomonas palustris strain TIE-1. Appl Environ Microbiol 71:44874496.

Johnson CM, Beard BL, Beukes NJ, Klein C, O'Leary JM. 2003. Ancient geochemical cycling in the Earth as inferred from $\mathrm{Fe}$ isotope studies of banded iron formations from the Transvaal Craton. Contributions to Mineralogy and Petrology 144:523-547.

Johnson CM, Roden EE, Welch SA, Beard BL. 2005. Experimental constraints on $\mathrm{Fe}$ isotope fractionation during magnetite and $\mathrm{Fe}$ carbonate formation coupled to dissimilatory hydrous ferric oxide reduction. Geochim Cosmochim Acta 67:963-993.

Karlin R, Lyle M, Heath GR. 1987. Authigenic magnetite formation in suboxic marine sediments. Nature 326:490-493.

Kirschvink, J.L., 1982. Paleomagnetic evidence for fossil biogenic magnetite in western Crete. Earth Planet Sci Lett 59:388-392.

Kirschvink JL, Chang S-BR. 1984. Ultrafine-grained magnetite in deep-sea sediments: Possible bacterial magnetofossils. Geol 12:559-562.

Komeili A, Li Z, Newman DK, Jensen GJ. 2006. Magnetosomes are invaginations organized by the actin-like protein MamK. Science 311:242-245.

Komeili A, Vali H, Beveridge TJ, Newman DK. 2004. Magnetosome vesicles are present prior to magnetite formation and MamA is required for their activation. Proc Natl Acad Sci USA 101:3839-3844.

Konhauser KO. 1998. Diversity of bacterial iron mineralization. Earth-Sci Rev 43:91-121.

Konhauser, KO. 2007. Introduction to Geomicrobiology. Blackwell Publishing, Oxford. $425 \mathrm{p}$.

Krapež B, Barley ME, Pickard AL. 2003. Hydrothermal and resedimented origins of the precursor sediments to banded iron formations: Sedimentological evidence from the early Palaeoproterozoic Brockman Supersequence of Western Australia. Sedimentology 50:979-1011.

Krieg NR, Hoffman PS. 1986. Microaerophily and oxygen toxicity. Annu Rev Microbiol 40:107-130.

Liu SV, Zhou J, Zhang C, Cole DR, Gajdarziska-Josifovska M, Phelps TJ. 1997. Thermophilic Fe(III)-reducing bacteria from the deep subsurface: the evolutionary implications. Science 277:1106-1109.

Lovley DR. 1990. Magnetite formation during microbial dissimilatory iron reduction. In Frankel RB, Blakemore RP, editors. Iron Biominerals. Plenum Press, New York. P 151-166.

Lovley DR, Lonergan DJ. 1990. Anaerobic oxidation of toluene, phenol, and p-crestol by the dissimilatory iron-reducing organism, GS-15. Appl Environ Microbiol 56:1858-1864.

Lovley DR, Stolz JF, Nord Jr. GL, Phillips EJP. 1987. Anaerobic production of magnetite by a dissimilatory iron-reducing microorganism. Nature 330:252254.

Lowenstam HA. 1981. Minerals formed by organisms. Science 211:1126-1131.

Lowenstam HA, Weiner S. 1989. On Biomineralization. Oxford University Press, New York. 324 p.

Mann S. 1988. Molecular recognition in biomineralization. Nature 332:119124.

Mann S, Archibald DD, Didymus JM, Douglas T, Heywood BR, Meldrum FC, Reeves NJ. 1993. Crystallization at inorganic-organic interfaces: Biominerals and biomimetic synthesis. Science 261:1286-1292.

McCabe C, Sassen R, Saffer B. 1987. Occurrence of secondary magnetite within biodegraded oil. Geol 15:7-10.

Meldrum FC, Heywood BR, Mann S, Frankel RB, Bazylinski DA. 1993. Electron microscopy study of magnetosomes in a cultures coccoid magnetotactic bacterium. Proc R Soc London B 251:231-236.

Moskowitz BM, Frankel RB, Bazylinski DA, Jannasch HW, Lovley DR. 1989. A comparison of magnetite particles produced anaerobically by magnetotactic 
and dissimilatory iron-reducing bacteria. Geophys Res Lett 16:665668.

Neilands JB. 1989. Siderophore systems of bacteria and fungi. In Poindexter JS, Leadbetter ER, editors. Bacteria in Nature. Plenum Press, New York. P. 141-163.

Petersen N, von Dobeneck T, Vali H. 1986. Fossil bacterial magnetite in deep-sea sediments from the South Atlantic Ocean. Nature 320:611615.

Roh Y, Liu SV, Li G, Huang H, Phelps TJ, Zhou J. 2002. Isolation and characterization of metal-reducing Thermoanaerobacter strains from deep subsurface environments of the Piceance Basin, Colorado. Appl Environ Microbiol 68:6103-6020.

Scheffel A, Gruska M, Faive D, Linaroudisn A, Graumann PL, Plitzko JM, Schüler D. 2006. An acidic protein aligns magnetosomes along a filamentous structure in magnetotactic bacteria. Nature 440:110-114.

Schopf JW. 1993. Microfossils of the Early Archean Apex chert: new evidence of the antiquity of life. Science 260:640-646.

Schopf JW, Packer BM. 1987. Early Archean (3.3-billion to 3.5-billion-yearold) microfossils from Warrawoona Group, Australia. Science 237:7073.

Schüler D, Baeuerlein E. 1998. Dynamics of iron uptake and Fe3O4 mineralization during aerobic and microaerobic growth of Magnetospirillum gryphiswaldense. J Bacteriol 180:159-162.

Short KA, Blakemore RP. 1986. Iron respiration-driven proton translocation in aerobic bacteria. J Bacteriol 167:729-731.

Slobodkin AI, Jeanthon C, Haridon SL, Nazina T, Miroschnichenko M, BonchOsmolovskaya E. 1999. Dissimilatory reduction of Fe(III) by thermophilic bacteria and archaea in deep subsurface petroleum reservoirs of western Siberia. Curr Microbiol 39:99-102.

Slobodkin AI, Reysenbach A-L, Strutz N, Dreier M, Wiegel J. 1997. Thermoterrabacterium ferrireducens gen. nov., sp. nov., a thermophilic anaerobic dissimilatory $\mathrm{Fe}$ (III)-reducing bacterium from a continental hot spring. Int $\mathrm{J}$ Syst Bacteriol 47:541-547.

Sparks NHC, Mann S, Bazylinski DA, Lovley DR, Jannasch HW, Frankel RB. 1990. Structure and morphology of magnetite anaerobically-produced by a marine magnetotactic bacterium and a dissimilatory iron-reducing bacterium. Earth Planet Sci Lett 98:14-22.
Thomas-Keprta KL, Bazylinski DA, Kirschvink JL, Clemett SJ, McKay DS, Wentworth SJ, Vali H, Gibson Jr EK, Romanek CS. 2000. Elongated prismatic magnetite $\left(\mathrm{Fe}_{3} \mathrm{O}_{4}\right)$ crystals in ALH84001 carbonate globules: potential martian magnetofossils. Geochim Cosmochim Acta 64:4049-4081.

Thomas-Keprta KL, Clemett SJ, Bazylinski DA, Kirschvink JL, McKay DS, Wentworth SJ, Vali H, Gibson Jr EK, McKay MF, Romanek CS. 2001. Truncated hexa-octahedral magnetite crystals in ALH84001: presumptive biosignatures. Proc Natl Acad Sci USA 98:2164-2169.

Torres de Araujo FF, Pires MA, Frankel RB, Bicudo CEM. 1986. Magnetite and magnetotaxis in algae. Biophys J 50:375-378.

Vainshtein M, Suzina N, Sorokin V. 1997. A new type of magnet-sensitive inclusions in cells of photosynthetic bacteria. Syst Appl Microbiol 20:182186.

Vainshtein M, Suzina N, Kudryashova E, Ariskina E. 2002. New magnetsensitive structures in bacterial and archaeal cells. Biol Cell 94:29-35.

Vali H, Weiss B, Li Y-L, Sears SK, Kim SS, Kirschvink JL, Zhang CL. 2004. Formation of tabular single-domain magnetite induced by Geobacter metallireducens GS-15. Proc Natl Acad Sci USA 101:16121-16126.

Vargas M, Kashefi K, Blunt-Harris EL, Lovley DR. 1998. Microbiological evidence for Fe(III) reduction on early Earth. Nature 395:65-67.

Walker JCG. 1984. Suboxic diagenesis in banded iron formations. Nature 309:340-342.

Weiner S, Dove PM. 2003. An overview of biomineralization processes and the problem of the vital effect. Rev Mineral Geochem 54:1-26.

Williams TJ, Zhang CL, Scott JH, Bazylinski DA. 2006. Evidence for autotrophy via the reverse tricarboxylic acid cycle in the marine magnetotactic coccus strain MC-1. Appl Environ Microbiol 72:1322-1329.

Yamaguchi KE, Johnson CM, Beard BL, Ohmoto H. 2005. Biogeochemical cycling of iron in the Archean Paleoproterozoic Earth: Constraints from iron isotope variations in sedimentary rocks from the Kaapvaal and Pilbara Cratons. Chem Geol 218:135-169.

Zhang C, Liu S, Phelps TJ, Cole DR, Horita J, Fortier SM. 1997. Physicochemical, mineralogical, and isotopic characterization of magnetite-rich iron oxides formed by thermophilic iron-reducing bacteria. Geochim Cosmochim Acta 61:4621-4632.

Zhang C, Vali H, Romanek CS, Phelps TJ, Lu SV. 1998. Formation of single domain magnetite by a thermophilic bacterium. Am Mineral 83:1409-1418. 